\title{
A PRELIMINARY ASSESSMENT OF THE PHYSICAL-CHEMICAL FEATURES OF WATER AND SEDIMENTS FROM DIFFERENT DELTAIC AQUATIC SYSTEMS. CASE STUDY: FORTUNA LAKE, MATITA LAKE AND MUSURA BAY DANUBE DELTA, ROMANIA
}

\author{
$\underline{\text { Irina Catianis }}{ }^{1}$, Iulian Pojar $^{1}$, Albert Scrieciu $^{1}$, Dumitru Grosu ${ }^{1}$, Ana Bianca Pavel${ }^{2}$
}

${ }^{1}$ National Institute of Marine Geology and Geoecology - GeoEcoMar, 23 - 25

Dimitrie Onciul Street, 024053 Bucharest, Romania, ${ }^{2}$ National Institute of Marine Geology and Geoecology - GeoEcoMar, 304 Mamaia Blv., 90058,

Constanta,Romania, E-mail: irina.catianis@geecomar.ro

\begin{abstract}
The deltaic aquatic systems are of significant importance, being the interface between the particular geographical environments and a much elaborated complex of ecosystems and biodiversity, the characteristics that confers the uniqueness of the Danube Delta territory. Due to natural and human-related pressures to which Danube Delta it is subject, it becomes imperative to diagnose and evaluate the quality of the environmental status in relation to the condition of the water and sediment characteristics. This paper aims to assess the preliminary environmental quality status (water and sediment) in three different aquatic systems situated in the Danube Delta edifice. A research survey was focused on specific sampling field activities, subsequent laboratory analysis, data processing and basic findings. In this sense, 26 water samples, 20 surficial sediment samples and 3 short cores were collected during May 2016, aiming to estimate the water-physical-chemical features and the lithological characteristics of the recent sediments. In water, the environmental indicators agreed generally with environmental standards. In sediments, the percentage distribution of the physical parameters varied according to the specific local environmental conditions of the investigated perimeters. The main findings emphasize the role of the local current conditions of the investigated lakes, sampling sites, seasonal changes in the water budget through hydrological network etc., which influences the water and sediment conventional variables. In conclusion, this study report satisfactory water quality conditions of the investigated lakes. As regards the sediments, the specific environmental conditions are the main factors that control the influx of allochthonous or autochthonous material.
\end{abstract}

Keywords: environment, physical-chemical, sediments, surface water, water quality

\section{Introduction}

The aim of this paper is to assess the water and sediment quality of three aquatic systems situated within the Danube Delta. Its peculiar geographical diversity of environments, climate conditions, its plentiful elaborating bodies of water, as well as unique species of flora and fauna might be susceptible to the environmental imbalance caused by natural and anthropogenic factors. Determining the surface water and sediment quality in the deltaic-lagoon areas is of great importance regarding the strengthening of analytically methods for evaluating the quality of natural investigated environments, the development of environmental knowledge status, as well as the environmental risks, along with management strategies and sustainable development of the Danube Delta Biosphere Reserve. In this context, the identification of the water and sediment quality through the medium of periodical surveillance is essential. This study is based on a preliminary characterization of water and sediment samples 
gathered from some control sections from Sulina Branch, a few connection canals and different lakes. It is worth mentioning that the analyses of water capture an instant snapshot panorama of the aquatic system environmental conditions at the moment of sampling.

\section{Materials and Methods (or Experimental)}

\subsection{Study area and the environmental setting}

The Danube Delta is the second largest river delta in Europe, after the Volga Delta, and is part of the vast hydro-sedimentary geosistem Danube River - its delta - coastal Black Sea, being the buffer interface between a large hydrological drainage network $\left(817000 \mathrm{~km}^{2}\right.$, that collect water and sediment loads from many countries) and the Black Sea semi-enclosed water body. Likewise, as an environmental system is one of the main integral parts of the Danube River - Danube Delta - Black Sea geoecosystem [1]. Its large extensions of surface waters, wetlands, woodlands, meadows, swamps, channels, streams, canals, shallow bays, ponds and numerous lakes, interconnected with swamps, reed-beds, isles and floodplains covers an area of approximately 5800 $\mathrm{km}^{2}$. The Danube Delta is apportioned into three main depositional systems: the delta plain, the delta front, and the prodelta. Danube Delta incorporates two main units - the upper fluvial delta plain that lies in the west, and, the fluvio-marine delta plain which is the lowermost, being displayed in the west and up to the Black Sea. These compartments are separated by the initial littoral ridge: Jibrieni-Letea-RăducuCeamurlia-Caraorman-Sărăturile-Perișor-Lupilor [2]. The investigated aquatic systems within this study were represented by Fortuna Lake, Matița Lake and Musura Bay. Additionally, were considered some sections of controls focalised on Sulina Arm, as well as some connection canals between lakes.

\subsection{Field Methods - Sampling Procedures}

The environment surveying (water and sediment characteristics) was performed within a sampling campaign held in the course of May-June 2016 (Fig. 1). The GPS coordinates, water depth, the main climatic parameters, as well as the Danube River quotas were constantly registered. In this sense, the sampling period was characterized by a high hydrological regime of the Danube River, with an average measured value of $278.17 \mathrm{~cm}$, value considered higher in comparison to the normal reference quota to the Tulcea Port $(180-200 \mathrm{~cm})$. The weather was specifically for that period with normal temperatures and rain episodes. Among the investigated lakes, the Fortuna Lake was the most plentiful with abundant submerged aquatic vegetation. The study was focused on field observations and measurements, as well as the analysis and strict interpretation of some water environmental indicators as: depth $(m)$, Secchi transparency $(\mathrm{m})$, temperature $\left(\mathrm{T}^{\circ} \mathrm{C}\right)$, dissolved oxygen - $\mathrm{O}_{2}(\mathrm{mg} / \mathrm{l})$, conductivity - EC $(\mu \mathrm{S} / \mathrm{cm})$, total dissolved solids - TDS $(\mathrm{mg} / \mathrm{l})$, water reaction ( $\mathrm{pH}$ units), oxido-reduction potential - ORP $(\mathrm{mV})$, turbidity (NTU), total suspended solids - TSS (mg/l), nitrite nitrogen - ${\mathrm{N}-\mathrm{NO}_{2}}^{-}(\mathrm{mg} / \mathrm{l})$, nitrate nitrogen - $\mathrm{N}-\mathrm{NO}_{3}{ }^{-}(\mathrm{mg} / \mathrm{l})$, soluble orthophosphates - P$\mathrm{PO}_{4}{ }^{3-}, \quad(\mathrm{mg} / \mathrm{l})$ and sulphates $-\mathrm{SO}_{4}{ }^{2-}(\mathrm{mg} / \mathrm{l})$. Withal, were considered the percentage distribution of the physical sediment parameters as moisture, dry content, total organic matter, total carbonates and minerogenic material attempting to estimate the type of the recent sedimentary accumulations. The field activities and measurements were 
carried out aboard the "Istros" RV which belongs to the National Institute of Marine Geology and Geoecology - GeoEcoMar, Romania.

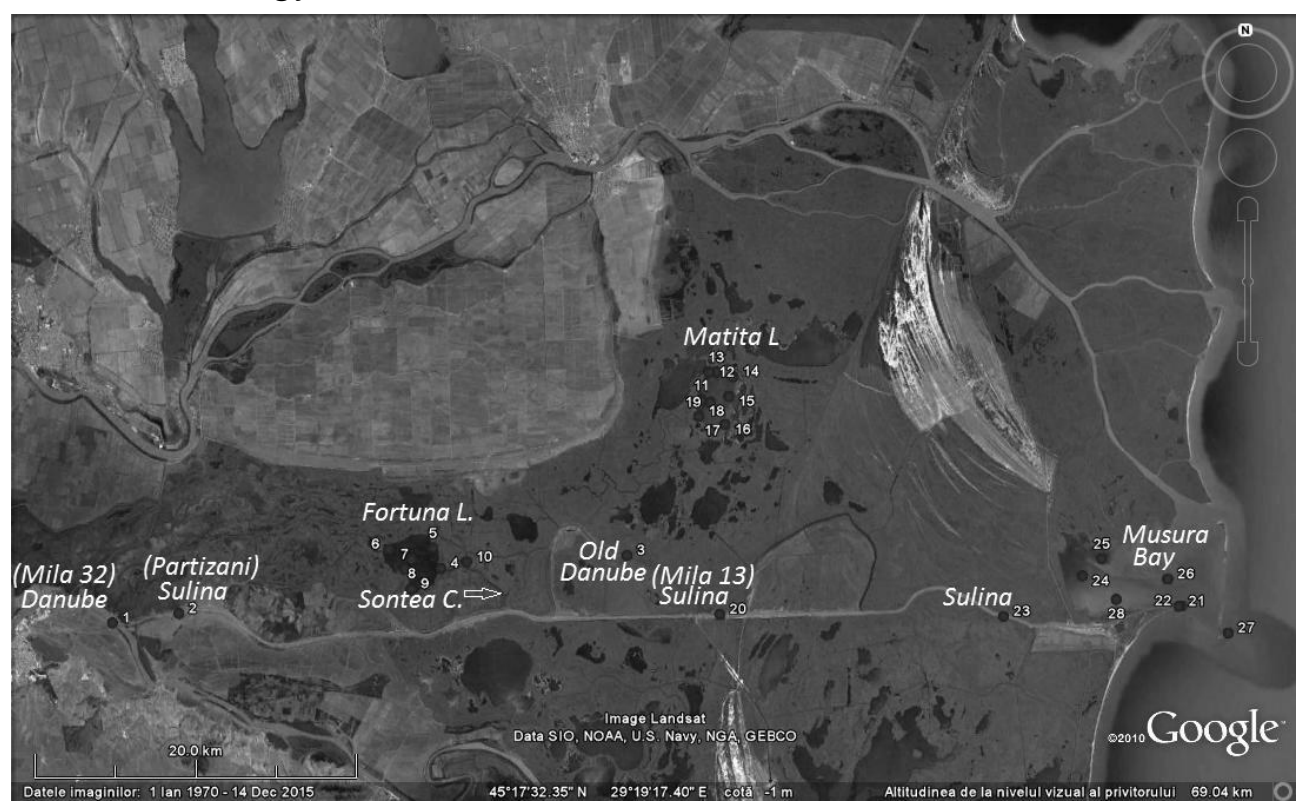

Figure 1. Geo-location of the water sampling sites within the Danube Delta area

The water and sediment sampling, as well as analytical operations were based on standard protocols and procedures. The surface water measurements were conducted in situ at each sampling site using the portable WTW Multiline P4 Multiparameter, $\mathrm{HACH} 2100 \mathrm{Q}$ - Turbidimeter and HACH 5000-UV-Vis-Spectrophotometer. The surficial sediments (sediment-water interface, 0-20 cm) were hand-sampled in each location using a Van-Veen grab sampler, and the core sediments were gathered using the Hydro-Bios bottom sampler. The subsequent laboratory analyses considered for the percentage distribution of the main lithological components were performed by the Loss of Ignition Method [3, 4, 5] using a high-temperature electric furnace SNOL $8.2 / 1100^{\circ} \mathrm{C}$.

\section{Results and Discussion}

a. The physical-chemical characteristics of surface waters

The surface water quality depends on the variability of parameters which may be changed significantly under the influence of natural conditions (seasonal flows, rainfall etc.) and as a result of anthropogenic impact (wastewater discharges), so it is important to analyse some distinct physical and chemical parameters. The analysis of some specific indicators to determine the state of surface water samples taken from investigated aquatic systems (lakes and canals) was conducted in accordance with Romanian environmental regulations [6].The concentration of TDS levels (Total Dissolved organic and inorganic Substances) was related to the level of TDS in water established for freshwater (0-1000 mg/l) and brackish water (1000 to 30,000 mg/l TDS) [7]. The levels of turbidity were linked to a regulation [8], (which stipulates 5 NTU admitted values and 10 NTU - exceptionally permissible values). The concentration of TSS (Total Suspended Solids) was compared to a standard [9], which provides values $<40 \mathrm{mg} / \mathrm{l}$ - as acceptable level of TSS in freshwater environments, and, respectively, values $<10 \mathrm{mg} / \mathrm{l}$ - as an acceptable level of TSS in the marine environment). The 
oxidation - reduction potential levels were assimilated to the range of ORP for natural waters (with values in the range $-500+700 \mathrm{mV}$ ) [10].

The Danube Delta water quality status is strongly influenced by the Danube River water quality, which is the main collector of all discharges of contaminated water (urban or industrial wastewater discharges insufficiently treated and/or agricultural discharges etc.) arising from the upstream riparian countries, as well as from the Romanian territory. In determining the status of water quality conditions (naturally and as a result of human impact) were selected the previously mentioned perimeters. The analytical data for these research areas provides some relevant information concerning the quality of investigating environments. For instance, the water $\mathrm{T}\left({ }^{\circ} \mathrm{C}\right)$ distribution in the control sections was consistent with seasonal climate variations expected in May. The higher $\mathrm{T}\left({ }^{\circ} \mathrm{C}\right)\left(21.7^{\circ} \mathrm{C}\right)$ was recorded in the DD16-03 (Old Danube - "The Big M" on the Sulina Branch) and the lowest $\left(18.9^{\circ} \mathrm{C}\right)$ was recorded at $D D 16-23$ (Sulina Port). The $\mathrm{pH}$ ranged from 7.83 to 8.45 ( $\mathrm{pH}$ units). All concentrations of $\mathrm{O}_{2}$ showed high values (8.33 to $10.33 \mathrm{mg} / \mathrm{l}$, respectively, from 89.4 to $112.5 \%$ ). These higher values can be attributed to a more advanced rate of natural water re-oxygenation. The $\mathrm{N}-\mathrm{NO}_{2}{ }^{-}$ $(0.02 \mathrm{mg} / \mathrm{l}), \mathrm{N}-\mathrm{NO}_{3}{ }^{-}(0.07 \mathrm{mg} / \mathrm{l})$ and $\mathrm{P}_{-} \mathrm{PO}_{4}{ }^{3-}(0.23 \mathrm{mg} / \mathrm{l})$ concentrations were low. The EC levels displayed values in the range $401-457(\mathrm{mS} / \mathrm{cm})$. The TDS scattering had values that are suitable for freshwaters. The highest TDS $(229 \mathrm{mg} / \mathrm{l})$ was recorded in DD16-03, and the lowest (201 mg/l) was observed in DD16-23. The $\mathrm{SO}_{4}{ }^{2-}$ dispersal had values between the intervals of $34-37(\mathrm{mg} / \mathrm{l})$. The water analyses carried out at Sulina Branch showed that turbidity was included in the following range $(10.6-39.6$ NTU). The relatively higher values were observed in DD16-01 (29.3 NTU), DD16-02 (39.6 NTU) and DD16-20 (19.6 NTU). The TSS concentrations had a mean value of $33.75 \mathrm{mg} / \mathrm{l}$. The highest value was registered at DD16-02 $(49 \mathrm{mg} / \mathrm{l})$, while the lowest value was found in DD16-03 (18 mg/l). The water transparency varied between 0.3$1 \mathrm{~m}$. The ORP level varied between interval of $12-71(\mathrm{mV})$, with a mean of $51.25(\mathrm{mV})$. Fortuna Lake - The water $\mathrm{T}\left({ }^{\circ} \mathrm{C}\right)$ dispersal expressed as mean value $\left(20.4^{\circ} \mathrm{C}\right)$ was in line with the seasonal variations in climate for May. The $\mathrm{pH}$ values extended from 7.75 to 8.6 ( $\mathrm{pH}$ units). The highest value $(8.6 \mathrm{pH})$ was recorded in DD16-09 (in the southern part of the lake) and the lowest, $7.75(\mathrm{pH})$ was observed in DD16-07 (in the southwestern part of the lake, next to Crânjală Ch.). The $\mathrm{O}_{2}$ concentrations fluctuated from 4.31 to $14.86(\mathrm{mg} / \mathrm{l})$, respectively from 47.9 to $164(\%)$.The lowest value $(4.31$ $\mathrm{mg} / \mathrm{l}$ ) was observed in $D D 16-07$, and the highest value (14.86) was registered in $D D 16$ 09. The mean value levels of the $\mathrm{N}-\mathrm{NO}_{2}{ }^{-}(0.02 \mathrm{mg} / \mathrm{l}), \mathrm{N}-\mathrm{NO}_{3}{ }^{-}(0.03 \mathrm{mg} / \mathrm{l})$ and $\mathrm{P}_{-} \mathrm{PO}_{4}{ }^{3-}$ $(0.37 \mathrm{mg} / \mathrm{l})$ were generally low; the $\mathrm{P}_{-} \mathrm{PO}_{4}{ }^{3-}$ highest value $(1.17 \mathrm{mg} / \mathrm{l})$ was registered in DD16-05 (in the north-eastern part of the lake, next to Fortuna 2 Ch.). The EC level founded by Fortuna $L$. indicates values in the range of $383-435(\mathrm{mS} / \mathrm{cm})$, with a mean of $417(\mathrm{mS} / \mathrm{cm})$. The TDS showed values that are proper for freshwaters. The highest value $(217.5 \mathrm{mg} / \mathrm{l})$ was recorded in DD16-07, and the lowest $(191.5 \mathrm{mg} / \mathrm{l})$ was observed in DD16-04 (Şontea Ch.) and DD16-06 (in the northwestern part of the lake). The $\mathrm{SO}_{4}{ }^{2-}$ dispersal indicated values in the range $34-57(\mathrm{mg} / \mathrm{l})$ and a mean of $44.33(\mathrm{mg} / \mathrm{l})$. It is noted that the turbidity values are in the range of 0.92 to 5.75 (NTU), with a mean value of 2.18 (NTU). The maximum value of 5.75 (NTU) was observed in DD16-09. With regard to the TSS results, it can be noticed values within the range of $5-10(\mathrm{mg} / \mathrm{l})$, with a mean value of $6.6(\mathrm{mg} / \mathrm{l})$. Water transparency fluctuated between $1-3 \mathrm{~m}$, with a mean of $1.77 \mathrm{~m}$. The ORP varied in the range of $15-73(\mathrm{mV})$, with a mean of $45.67(\mathrm{mV})$. Matița Lake - The water $\mathrm{T}\left({ }^{\circ} \mathrm{C}\right)$ spreading varied in the range of 21.2 to $22,2\left({ }^{\circ} \mathrm{C}\right)$, and had a mean of $21.85^{\circ} \mathrm{C}$. The $\mathrm{pH}$ fitted in the range of $\mathrm{pH}$ with values ranging from 7.6 to $8.44(\mathrm{pH})$, and a mean value of $8.17(\mathrm{pH})$. The $\mathrm{O}_{2}$ variation showed a relatively large 
ecart, namely from 6.2 to $11.85(\mathrm{mg} /) \mathrm{l}$, and, respectively, 68.9 to $136.7(\%)$, and a mean of $9.92(\mathrm{mg} / \mathrm{l})$ and $112.88(\%)$. The $\mathrm{N}-\mathrm{NO}_{2}{ }^{-}$and $\mathrm{N}-\mathrm{NO}_{3}{ }^{-}$with similar mean value of $0.01(\mathrm{mg} / \mathrm{l})$ are compliant with environmental specifications. Instead, the $\mathrm{P}_{-} \mathrm{PO}_{4}{ }^{3-}$ values, that are included in the range of 0.06 to $1.87(\mathrm{mg} / \mathrm{l})$, and with a mean of 0.93 $(\mathrm{mg} / \mathrm{l})$, exceed the maximum concentration level in some water samples. High values were detected in the northern part of the lake in $D D 16-13(1.53 \mathrm{mg} / \mathrm{l})$, then in the southern part of the lake, in $D D 16-17(1.06 \mathrm{mg} / \mathrm{l})$, as well as in the center of the lake, in the DD16-19 (1.86 $\mathrm{mg} / \mathrm{l})$. These results exceed the limit values settled for Class $\mathrm{V}$ of quality (bad ecological status) provided by the regulations. The EC, TDS and $\mathrm{SO}_{4}{ }^{2-}$ levels were below the maximum allowable amount stipulated by the referenced regulations. Turbidity presents a relatively wider variation, with values ranging from 1.42 to 10.1 (NTU). The TSS had a mean of $9 \mathrm{mg} / \mathrm{l}$. Water transparency fluctuated between 1.5-2.5 m, with a mean of $1.83 \mathrm{~m}$. The ORP fluctuated in the range of 45-71 $(\mathrm{mV})$, with a mean of $54(\mathrm{mV})$. Musura Bay - The water $\mathrm{T}\left({ }^{\circ} \mathrm{C}\right)$ scattering was in the range of 18.9 to $20.2^{\circ} \mathrm{C}$, and had a mean of $19.9^{\circ} \mathrm{C}$. The $\mathrm{pH}$ measurements indicated a slightly alkaline character, ranging from 8.14 to 8.93 (pH units), and a mean of 8.58 $(\mathrm{pH})$. The $\mathrm{O}_{2}$ presented higher values, ranging from 8.12 to $11.28(\mathrm{mg} / \mathrm{l})$ and, respectively from 97.9 to 134.1 (\%). The ${\mathrm{N}-\mathrm{NO}_{2}}^{-}(0.01$ to $0.03 \mathrm{mg} / \mathrm{l})$ and $\mathrm{N}-\mathrm{NO}_{3}^{-}(0.02$ to $0.09 \mathrm{mg} / \mathrm{l})$ variations showed low values. The mean value of $\mathrm{P}_{-} \mathrm{PO}_{4}{ }^{3-}(1.06 \mathrm{mg} / \mathrm{l})$ was increased, the higher values being encountered in the northern part of the bay, namely in the DD16-25 (1.83 mg/l), then in the middle of the basin, at DD16-26 $(1.67 \mathrm{mg} / \mathrm{l})$, and, at the exit of the bay, at $D D 16-27(1.60 \mathrm{mg} / \mathrm{l})$. These values exceed the maximum content level established for Class $\mathrm{V}$ of quality that is foreseen in the standards. The EC levels presented values included in a relatively wider ecart, with values ranging between 362- 3300 (mS/cm). Higher values are found in the following samples: DD1621 (1732 mS/cm), DD16-26 (2170 mS/cm) and DD16-27 (3300 mS/cm). Concentration of TDS showed values that are both proper for freshwaters and brackish water. The $\mathrm{SO}_{4}{ }^{2-}$ levels pointed out relatively higher values compared to the previously discussed lakes, having results included in the range of 31-91 $(\mathrm{mg} / \mathrm{l})$. Some values exceed the maximum content level settled for Class 1 of quality (good quality) that is specified in normative. They were encountered in the following sites: DD16-21 (79 mg/l), DD16-25 $(79 \mathrm{mg} / \mathrm{l})$ and $D D 16-26(91 \mathrm{mg} / \mathrm{l})$. The turbidity indicated values in the range of 2.42 to 43 (NTU). Relatively higher values were recorded in samples DD16-21 (43 NTU), DD16-24 (12.5 NTU), DD16-26 (6.05 NTU), DD16-27 (19.5 NTU) and DD16-28 (24.4 NTU). The TSS levels had values included in the range of $8-57(\mathrm{mg} / \mathrm{l})$, with a mean of $27.5 \mathrm{mg} / \mathrm{l}$. It can be reported significantly increased values of the TSS content with values above $10 \mathrm{mg} / \mathrm{l}$. The ORP fits within the normal range, with both negative and positive variations, respectively, from -20 to $+31(\mathrm{mV})$, and a mean of $20(\mathrm{mV})$.

\subsection{The lithological characterization of lacustrine sediments}

Sediment quality assessment is a key component of the evaluation status of aquatic ecosystems. Aquatic sediments represent a favorable habitat for many plants and animal organisms, being loaded with a number of nourishing compounds. At the same time, the aquatic sediments represent the final receptors for a wide range of pollutants, thus representing a potential source of contamination of the aquatic food chain. The impact of human activity plays a major role in increasing the variability of existing concentrations of chemical compounds in the bottom sediments. To assess the quality state of deltaic lacustrine sediments were investigated a series of sediment samples collected from Sulina Branch, Fortuna Lake, Matița Lake and Musura Bay. The LOI 
method used within this study can actually be considered as a proxy indicator for the preliminary assessment of the allochthonous or the autochthonous source of these aquatic systems. A general estimation of the composition of sediments can be performed based on the weight percentages in function of the total organic matter content (\% TOM), the total carbonate content (\%CAR) and siliciclastic fraction (\% SIL), calculated by the total weight of dry sediment [11]. Further on, is presented an empirical classification of sediments according to the percentage of the carbonate content [12]: non-carbonate sediments containing less than $0.5 \%$ by weight of dry sediment, a lower carbonate content sediments containing carbonate from $0.5 \%-1 \%$ of the total weight of dry sediment and carbonate sediments containing more than $1 \%$ of the total weight of the dry sediment. The grab and core sediment sampling site locations are shown in the figure 2 .

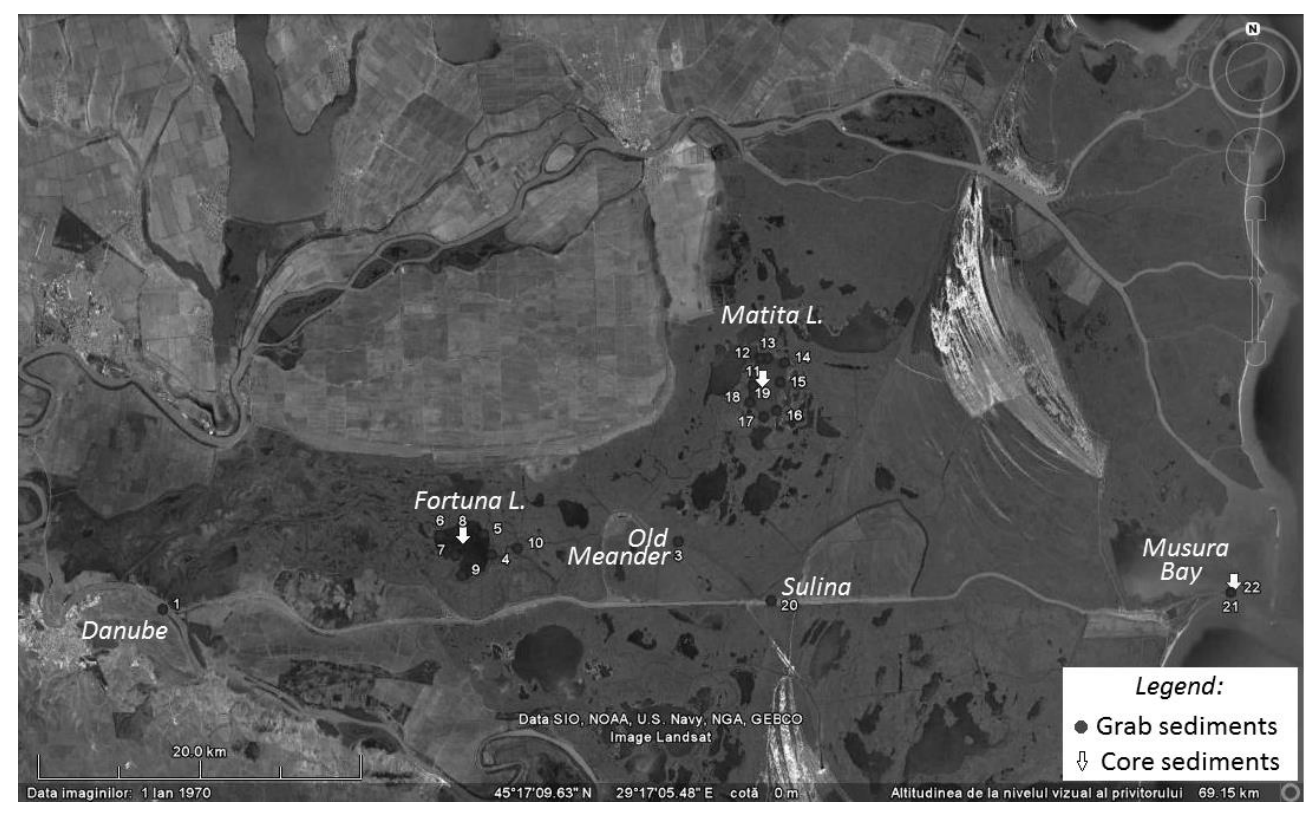

Figure 2. Geo-location of the sediment sampling sites within the Danube Delta area

\subsubsection{The analysis of surficial sediments (water/sediment interface)}

The lithological analyses performed on these sediments showed significant variations in the main lithological components. Thus, the average (\%) TOM content in the Danube River and Sulina Arm samples reached low levels as follows: $18.73 \%$ in DD1601 (Danube-Mila 32) and 17.00\%, in DD16-20 (Sulina - Mila 13) The (\%) CAR content fluctuated, with relatively high values, exceeding $1 \%$ of the total weight of dry sediment, as follows: $4.51 \%$ in DD16-01, and 6.97\% in DD16-20. The (\%) SIL amount presented higher values, over $50 \%$ of the total weight of dry sediment, as follows: $76.76 \%$ in $D D$ 16-01 and $76.03 \%$ in DD16-20. A quite different situation was observed in some certain connection channels samples, e.g., the (\%) TOM distribution presented a higher percentage, having the following values: $41.05 \%$ in DD16-03, 37.05\% in DD16-04 and $40.10 \%$ in DD16-10. The (\%) CAR content was high, with increased values over $1 \%$ of the total weight of dry sediment, as follows: $4.11 \%$ in DD16-03, 22.44\% in DD16-04 and $7.02 \%$ in $D D 16-10$. The increased carbonate fraction of the sample $D D 16-04$ is represented mainly by the large or smaller fragments of shells - lumachelle, which could not be easily removed from the sediment mass prior to lithological analyses. Then, the (\%) SIL content showed increased values, e.g., $54.84 \%$ in DD16-03, $40.51 \%$ 
in $D D 16-04$, and $52.88 \%$ in $D D 16-10$. On the basis of the acquired results it can be asserted that these sediments belong to the category of mineral sediments (loaded with a high content of minerogenic material), and that, subsidiary passing into mineral - organic sediments, presenting also a relatively pronounced carbonated feature. Fortuna Lake - The main apportionment is represented by the total organic matter, with a relatively higher quota from the whole mass of the sediments, and with a mean of $58.94 \%$ and a wide range of variation (28.91 to $74.58 \%$ ). The (\%) CAR amount concentrated a small quantum, with mean values relatively higher, exceeding $1 \%$ of the total weight of dry sediment, ranging from 3.48 to $6.92 \%$ and a mean of $5.12 \%$. The (\%) SIL component showed high values, over $50 \%$ of the total weight of dry sediment, which are integrated into a wide range of variation (21.94 to $65.64 \%$ ) and a mean of $36.29 \%$. Based on the results, it can be appreciated that the Fortuna $\mathrm{L}$. sediments belong to the category of organic sediments (loaded with a high content of organic matter), and that, subsidiary passing into organic - mineral sediments, presenting also a relatively pronounced carbonated feature. Matița Lake - The analyses report denoting variations of the main lithological components. Thus, it is observed that the (\%) TOM rate have higher values included in a wide range of variation (33.30-83.04 \%), and a mean of $68.29 \%$. The (\%) CAR scattering falls within a relatively wide range of variation (1.15 to $8.29 \%$ ) and a mean of $4.55 \%$. The (\%) SIL content falls within a relatively wide range of variation (12.97 to $59.40 \%$ ) and a mean of $27,16 \%$. According to these results it can be affirmed that the sedimentary accumulations of recent lacustrine sediments within the Matița L. belong to the category of organic sediments (rich and very rich in organic matter), subsequently followed by organic - mineral sediments, and a considerable higher carbonate content, too.

\subsubsection{The analysis of bottom (core) sediments}

The study of sediment cores is very important for assessing the human impact on the environment. In this sense were gathered 3 short cores from Fortuna L., Matița L. and Musura Bay. The core designated as DD16-08 (41 cm length) was taken from the central part of the Fortuna Lake. The analyses showed that the main component of bottom sediment core was represented by the (\%) TOM fraction; the values were higher than $50 \%$ of the total weight of dry sediment, with a mean of $53.59 \%$ and a wide range of variation (39.97 to $73.35 \%$ ). The (\%) CAR content was fluctuating $(2.13 \%-8.90 \%)$, resulting a mean of $5.87 \%$. The (\%) SIL amount presented values between $22.10 \%-55.04 \%$, and an average of $40.54 \%$. Based on the outcomes it can be estimated that the Fortuna L. sediments belong to the category of organic sediments (rich and very rich in organic matter), subsequently followed by organic mineral sediments, and considerable higher carbonate content, too. The short core labelled as DD16-19 (48.5 cm length) was collected from the central area of the Matița Lake. The analyses conducted on core sediments showed important changes in the main lithological components. The (\%) SIL fraction represents the largest quantum, showing values included in a wider gap variation (18.09 to $88.75 \%$ ) and a mean of $52.00 \%$. The (\%) TOM amount showed higher values in the upper part of the core which progressively decreases towards the bottom of the core; it was registered values that fall within a range of 3.34 to $77.27 \%$ and an average of $39.58 \%$. The (\%) CAR content was variable presenting values that are included in a relatively wide range $(4.65 \%-16.40 \%)$ and an average of $8.42 \%$. In line with the obtained results it can be settled that the sediment samples within the Matița L. could be linked to the category 
of mineral accumulations, subsequently followed by organic-mineral sediments, and a significant carbonate content, as well. The DD16-22 (50.5 cm length) core was taken from the southern part of the Musura Bay. The lithological parameters showed that the main component of the core sediments was mainly represented by the (\%) SIL fraction, showing a high content displayed in a wide range of variation (55.97 to $75.25 \%$ ), and a mean of $65.49 \%$. The (\%) CAR content is variable, being represented by values ranging between $2.80 \%-4.57 \%$ and a mean of $3.49 \%$. The (\%) TOM amount presented values between $20.43 \%-40.74 \%$ and an average of $31.01 \%$. According to the attained results it can be estimated that the tested core samples belong to the category of mineral sediments (loaded with a high content of minerogenic material), subsequently followed by a mineral - organic sediments, having also a relatively significant carbonated content.

\section{Conclusions}

The overall acquired results of this study have sketched a general overview regarding the main surface water physical-chemical features and the main physical characteristics of the sediments. Generally, the physical - chemical parameters indicate a normal trend in terms of water quality in accordance with current regulations. Mostly, there were no significant overruns, except for a few situations, that exceed the maximum content level recommendations. It's about the concentration and dynamics of soluble orthophosphates $\left(\mathrm{P}-\mathrm{PO}_{4}{ }^{3-}\right)$ encountered at some certain sites from Matița and Musura Bay. In most cases, high concentrations of phosphates can be corroborated with algae blooms. Certainly, that should not be excluded any anthropogenic sources (e.g., discharge of domestic wastewater, industrial effluent, agriculture etc.) or, probably, the remobilization of the internal load of phosphorus from sediments back into the overlying water. In addition, were observed some elevated levels of electro conductivity recorded in the Musura Bay. Here, the higher values of certain indicators as electrical conductivity, total dissolved solids and sulfates, compared to the other investigated lakes (freshwater environments) are somewhat expected, considering that the investigated environment has a relatively high salinity. Sediments are an important compartment in the energy flux (bio-geo-chemical cycle) of aquatic ecosystems. Generally speaking, the recent accumulations of sediments may have a mineral or organic nature, distributed in different proportions according to the type of aquatic receptor basin (river, lake etc.) or due to the anthropogenic impact. According to their origin, the sediments may be allochthonous sediments (sedimentary material, sand, silt etc. transported through a drainage basin) or autochthonous sediments (organic sediment accumulations derived as a result of various bio-geochemical in-lake processes and/or erosion processes, transport, deposition). In this context, the lithological analyses reveal an areal differentiation of investigating sediments, according to the weight percentage proportion of the main constituents: sedimentary material and organic input material. So, it was differentiated accumulations of sediments with high levels of siliciclastic content which are typical for areas directly influenced by the Danube River freshwater and sediment input, as well as sediments with high levels of organic content, which are characteristics for confined areas, or, situated at a long distance from fluvial inputs. 


\section{Acknowledgements}

The research leading to these results was financed from the Romanian National Authority for Scientific Research and Innovation - ANCSI -"Program Nucleu 37N/2016 - Proiect PN 1645 $0104 "$.

\section{References}

[1] Gâştescu, P. and Ştiucă, R. (2008). Delta Dunarii. Rezervatie a biosferei [The Danube Delta - A Biosphere Reserve], CD Press Publishing House, Bucharest, 400 p. [in Romanian]

[2] Panin, N. (1996). Danube Delta: Genesis, evolution, geological setting and sedimentology, GeoEco-Marina, 1, 7-23.

[3] Dean, W.E. (1974). Determination of carbonate and organic matter in calcareous sediments and sedimentary rocks by loss on ignition: comparison with other methods, J. Sediment. Petrol., 44, 242-248.

[4] Heiri, O., Lotter, A.F., and Lemcke, G. (2001). Loss on ignition as a method for estimating organic and carbonate content in sediments: reproducibility and comparability of results, $J$. Paleolimnol., 25, 101-110.

[5] Santisteban, J., I., Mediavilla, R., Lopez-Pamo, E., Dabrio, C., J., Ruiz Zapata, M., B., Garcia, M., J., G., Castano, S. \& Martinez-Alfaro, P., E., (2004). Loss on ignition: a qualitative or quantitative method for organic matter and carbonate mineral content in sediments? Journal of Paleolimnology, 32, 287-299.

[6] Normative 161/2006 - Standard on surface water quality classification for determination of the ecological status of Water bodies, Annex C - Elements and physical-chemical quality standards in water, published in Romanian Official Monitor, part I, no. 511 bis, from 13th of June, 2006.

[7] https://en.wikipedia.org/wiki/Total dissolved solids.

[8] STAS 6323 - 88, Apă potabilă. Determinarea turbidităţii.

[9] ANZECC 2000 Guidelines - Australian and New Zealand Guidelines for Fresh and Marine Water Quality, http://www.mfe.govt.nz/fresh-water/tools-and-guidelines/anzecc-2000guidelines.

[10] Sigg L. (2000). Redox Potential Measurements in Natural Waters: Significant Concepts and Problems. In H.D. Schulz, W. R. Fischer, J. Bottcher and W.H.M. Duijinisveld (Eds) Redox: Fundamentals, Processes and Applications, Springer, Berlin, Germany.

[11] G. van der Veer (2006) - Geochemical soil survey of the Netherlands, NGS 347.

[12] De Bakker, H. \& Schelling, J. (1989), Systeem van bodemclassificatie voor Nederland: de hogere niveaus, 2nd edition. Centre for Agricultural Publishing and Documentation, Wageningen, $209 \mathrm{pp}$ 